\title{
Effects of Supplementing Laying Hens with Purified Amino Acid Prepared from Animal Blood
}

\author{
N. Joshi ${ }^{a}$, T.G. Wandita ${ }^{a}$, S. Yang ${ }^{b}$, H. Park ${ }^{c}$, \& S.G. Hwang ${ }^{\mathrm{a}, *}$ \\ a Department of Animal Life and Environmental Science, Hankyong National University, \\ Anseong-si, 456-749 South Korea \\ ${ }^{\mathrm{b}}$ National Institute of Animal Science, RDA, South Korea

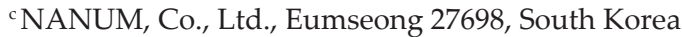 \\ "Corresponding author: sghwang@hknu.ac.kr \\ (Received 12-11-2018; Revised 30-01-2019; Accepted 04-02-2019)
}

\begin{abstract}
The objective of the experiment was to investigate the effects of supplementing laying hens with purified amino acids (PAA) derived from the blood of animal slaughter house on their egg production, egg quality, and immune response. The experiment was based on completely randomized design. A total of 144 Isa Brown laying hens (56-weeks old) were randomly allotted to 4 treatments with 4 pen replications (control, T1: $0.05 \%$, T2: 0.1\%, and T3: 0.5\% PAA). Each pen housed nine laying hens. The laying hens were reared under a deep litter system. Once a week, a total of 12 eggs of each treatment were collected for egg quality analysis. At the end of the experiment, blood samples were collected for biochemical analysis and cytokines profiles using ELISA kit assays. Hen day egg production and hen house egg production increased significantly $(P<0.05)$ along with the increase in PAA supplementation. The average egg weight increased significantly $(P<0.05)$ with PAA supplementation. Significant differences $(\mathrm{P}<0.05)$ were also found in egg shell strength, shell thickness, and albumen ratio. Blood biochemical variables, such as glucose, total cholesterol, blood urea nitrogen (BUN), total bilirubin, and glutamate oxalate transaminase (GOT) were within the normal range. However, the glucose was highest in the control group. Whereas, the total cholesterol and total bilirubin were highest in T2 as compared to control group. Plasma immunoglobulin A (IgA) and immunoglobulin G (IgG), interleukin-1 (IL-1), interleukin-2 (IL-2) concentrations were not affected by PAA supplementation. Plasma interferon gamma (IFN $\gamma$ ) of PAA supplemented treatment groups was significantly $(\mathrm{P}<0.05)$ lower than the control group. However, tumor necrosis factor alpha (TNF $\alpha)$ was significantly $(\mathrm{P}<0.05)$ higher in $\mathrm{T} 2$. On the basis of these results, we conclude that PAA supplementation improved the production performance of laying hens without affecting their health.
\end{abstract}

Keywords: animal blood; purified amino acid; laying hens; egg production; egg quality

\section{INTRODUCTION}

Blood is one of the unavoidable by-products of slaughterhouses as it comprises $4 \%$ of live animal weight. The blood produced from slaughterhouses is considered a problem as it is an environmental pollutant if discarded directly (Bah et al., 2012; Fearon et al., 2014). However, blood collected from abattoirs can be processed and used as a valuable source of protein. The use of locally available alternative feed resources aids in producing cheaper animal proteins (Melesse et al., 2011; Mohammed et al., 2012; Moreki \& Tiroesele, 2012). Blood and plasma proteins have also been utilized as high quality ingredients in feed for farm animals due to their nutritional benefits (Hejnfelt \& Angelidaki, 2009), replacing increasingly expensive traditional protein sources.

In general, plant proteins are deficient in important essential amino acids for poultry, i.e. lysine and methio- nine, whereas blood meal is rich in both of these amino acids (Sklan \& Noy, 2004). Feeding laying hens with high-protein diets is reported to improve body weight gain, egg production, and egg quality (Novak et al., 2004). The protein composition of egg varies considerably from plant and animal proteins; thus the availability of specific essential amino acid can have potential to affect the production performance of the laying hens (Ramsay \& Houston, 1998).

The proteins found in animal bodies are composed of 22 amino acids, and all of these are physiologically essential. Among the 22 amino acids, 10 amino acids, collectively referred to as essential amino acids, cannot be synthesized by poultry, and thus must be supplied in their diet for maintenance, growth, and production (Ravindran \& Bryden, 1999). The purified amino acid prepared from the blood collected from slaughterhouse is a good source of protein as its essential amino acids content is high (Ambardekar et al., 2009) and thus 
improves the quality of primary protein sources in poultry diets. The purified amino acid has a positive effect on the growth performance of broiler chicken (Wandita, 2018). However, the effects of supplementing laying hens with purified amino acids from animal blood have not been previously reported. Moreover, the use of low crude protein, crystalline amino acid supplemented diets is gaining momentum as it reduces excretion of nitrogen (Osada et al., 2011). However, the cost of crystalline amino acids is relatively high; thus, the use of low protein, amino acid supplemented diets is relatively expensive compared to that of using conventional dietary protein levels (Kwshavarz \& Austic, 2004). Previous studies have reported that, low protein; amino acid supplemented diets did not improve the egg production and egg weight (Harms \& Russell, 1993). Tenesa et al. (2016) reported that diets with a high proportion of crude protein $(17 \%)$ with amino acid supplementation had a positive impact on egg production and were beneficial to intestinal micro flora. Reducing the crude protein concentration in diets and supplementing diets with amino acids seems to have varied effects in laying hens. Therefore, the present study was designed to determine the effect supplementing laying hens with purified amino acids as a top dressing in corn soybean based basal diet. In this study, we evaluated the effects of purified amino acid supplementation on egg production and immune response of laying hens.

\section{MATERIALS AND METHODS}

\section{Purified Amino Acids}

Purified amino acids (PAA) were provided by Nanum Co., Eumsung-gun, Chungcheongbuk-do 27698, South Korea. PAA were prepared from animal blood collected hygienically from slaughterhouses. The collected blood was pulverized and then fermented and enzymatically digested under controlled condition. The resulting product was dehydrated and sterilized to produce the final product. The nutrient composition of the purified amino acid is shown in Table 1.

\section{Laying Hens and Experimental Design}

This experiment was designed to investigate the effects of four different levels of purified amino acid supplementation (Control: 0\%; T1: $0.05 \%$ of PAA supplementation; T2: $0.1 \%$ of PAA supplementation; T3: $0.5 \%$ of PAA supplementation) on laying hens. All the laying hens were reared on corn soyabean based basal diet (2800 kcal/kg Metabolizable energy, 17\% Crude Protein). The PAA were supplemented as a top dressing. A total of 144 laying hens were divided into 4 treatment groups based on completely randomized design in a research farm facility in Anseong, South Korea. Each treatment group had 4 replicate pens, with 9 laying hens in each replicate pen. Each pen was provided with 2 nesting boxes (10"deep $\times 12^{\prime \prime}$ wide and 10" high). The hens were reared on deep litter system; on floor made of concrete but covered with saw dust. The laying hens used in this experiment were 56 weeks old commercial laying hens
(Isa Brown) and the experiment lasted for 60 days. The laying hens were maintained on $16 \mathrm{~h}$ of light: $8 \mathrm{~h}$ dark cycle. The handling protocol of Hankyong National University Animal Care and Use Committee was followed in this study. The protocol ensures proper care and treatment of the experimental laying hens. Laying hens were given a week to adapt before the start of the experimental period. They were fed once a day with basal ration based on the Korean Nutrient Requirements Standards and water was provided ad-libitum through nipple drinking system. The composition of the basal diet used in the experiment is presented in Table 2. Feed supply was supplied at the rate of $110 \mathrm{~g}$ per birds per day and leftover was recorded every day in order to determine the average daily feed intake and average daily gain. Body weight was determined at the beginning and at the end of experiment. The overall mortality rate (Number of laying hens died/Total number of laying hens $\times 100$ ) for the laying hens was recorded to be $3.4 \%$ for the experimental period of 60 days.

\section{Egg Production and Egg Quality}

Eggs were collected from the nesting boxes and their total number and weight were recorded daily. The eggs were labeled according to the treatment groups. The experiment was carried out for 60 days. Every week, 12 eggs from each treatment were weighed (Ohaus EPG214C with $210 \mathrm{gm}$ weighing capacity and $0.1 \mathrm{mg}$ readability) and analyzed for both internal and exter-

Table 1. Nutrient compositions of the purified amino acid (PAA) used in the experiment

\begin{tabular}{lc}
\hline \multicolumn{1}{c}{ Nutrients } & Concentration \\
\hline Moisture, (\%) & 3.79 \\
Crude protein, (\%) & 93.37 \\
Ether extract, (\%) & 0.84 \\
Crude fiber, (\%) & 0.39 \\
Gross energy (kcal/kg) & 5374.00 \\
Calcium (mg/kg) & 406.63 \\
Phosphorous (mg/kg) & 1676.12 \\
Cysteine, (\%) & 1.041 \\
Methionine, (\%) & 0.458 \\
Aspartate, (\%) & 10.576 \\
Threonine, (\%) & 3.407 \\
Serine, (\%) & 4.565 \\
Glutamine, (\%) & 8.875 \\
Glycine, (\%) & 3.787 \\
Alanine, (\%) & 6.602 \\
Valine, $(\%)$ & 6.483 \\
Isoleucine, (\%) & 0.835 \\
Leucine, (\%) & 11.654 \\
Tyrosine, (\%) & 2.100 \\
Phenylalanine, (\%) & 6.219 \\
Lysine, (\%) & 7.313 \\
Histamine, (\%) & 5.703 \\
Arginine, (\%) & 3.809 \\
Proline, (\%) & 2.674 \\
\hline
\end{tabular}


Table 2. Nutrient compositions of laying hen basal diets used in the experiment

\begin{tabular}{lc}
\hline Ingredients & Concentration (\%) \\
\hline Corn $(8.6 \% \mathrm{CP})$ & 64.63 \\
Soybean meal $(48 \% \mathrm{CP})$ & 23.30 \\
Wheat barn & 1.80 \\
Corn gluten meal & 3.00 \\
Soybean oil & 2.50 \\
Dicalcium phosphate & 1.92 \\
Limestone & 1.25 \\
Salt & 0.25 \\
L-Lysine & 1.22 \\
Dl -methionine & 0.25 \\
Premix & 1.00 \\
Crude protein, \% & 17.00 \\
Methionine+Cysteine+MHA & 0.70 \\
\hline ME, kcal/kg & 2800.00 \\
\hline Note: MHA= Methionine Hydroxy & Analogue; \\
energy &
\end{tabular}

nal variables including egg shell strength, thickness, albumen ratio, yolk albumen ratio, Haugh unit, etc. Mitutoyo Coolant proof Digital micrometer $(0-25 \mathrm{~mm}$ \#293-340-30) was used to measure the shell thickness. An EG-001 egg shell strength tester (FHK NFN388, FHK, Japan) was used to measure shell strength. The minimum force that cracked the shell was recorded in terms of kilogram-force $(\mathrm{kgf})$. The other variables were calculated as follows:

1. Hen day egg production $(\mathrm{HDEP})=($ Total number of egg produced on the day / Total number of hens present on that day) $\times 100$

2. Hen housed egg production $($ HHEP $)=($ Total number of eggs laid on that day / Total number of hens housed at the beginning of laying period) $\times 100$

3. Albumen index $=[$ Albumen height $(\mathrm{mm}) /$ Albumen width $(\mathrm{mm})] \times 100 \%$

4. Albumen ratio $=[$ Albumen weight $(\mathrm{g}) /$ Egg weight $(\mathrm{g})] \times 100 \%$

5. Yolk index $=[$ Yolk height $(\mathrm{mm}) /$ Yolk width $(\mathrm{mm})] \times$ $100 \%$

6. Yolk ratio $=[$ Yolk weight $(\mathrm{g}) /$ Egg weight $(\mathrm{g})] \times 100 \%$

7. Yolk : Albumen ratio $=[$ Yolk weight $(\mathrm{g}) /$ Albumen weight $(\mathrm{g})] \times 100 \%$

8. Haugh unit= the Haugh Unit (HU) score is calculated using the egg weight and albumen height (Haugh, 1937). The formula used to calculate the Haugh unit is as follows: $\mathrm{HU}=100 \log _{10}$ $\left(\mathrm{H}+7.5-1.7 \mathrm{~W}^{0.37}\right)$

Where, $\mathrm{H}$ is the observed height of the albumen at the boundary with the yolk (in $\mathrm{mm}$ ) and $\mathrm{W}$ is weight of egg in grams. *Note that P6085 spherometer (tripod micrometer) with an accuracy of $0.01 \mathrm{~mm}$ was used to measure the yolk and albumen height.

\section{Blood Parameters and Plasma Immunoglobulin}

At the end of the experiment, blood samples were collected randomly from the 10 laying hens from each treatment group. Immediately after drawing blood, plasma samples were obtained by centrifuging at 3,000 r.p.m. for $10 \mathrm{~min}$ at $4{ }^{\circ} \mathrm{C}$ and then stored at $-70{ }^{\circ} \mathrm{C}$ until analysis. Plasma biochemical analyses (glucose, total cholesterol, total bilirubin, blood urea nitrogen, glutamate oxalate transaminase, and glutamate pyruvate transaminase) was conducted using SPOTCHEM EZ SP-4430. The samples were also analyzed for the concentration of pro-inflammatory markers IgA (CSBE11232Ch), IL-1 (CSB-E10069), IL-2 (CSB-E06755Ch), TNF $\alpha$ (CSB-E11231Ch), and IFN $\gamma$ (CSB-EO8550Ch)) with the aid of commercial ELISA Kit (Cusabio, Biotech Co., Ltd., Wuhan, China). Plasma concentrations of IgG ((Competitive EIA)-LS-F4752) were measured using a commercial Chicken IgG ELISA kit (LifeSpan BioSciences, Inc., Seattle, WA98121, USA). All the analyses were performed following the manufacturers' instructions and the absorbance was read with the aid of spectrophotometer (infinite F50 TECAN).

\section{Statistical Analysis}

All the experiments were replicated according to the requirement and data are expressed as the mean \pm SD (standard deviation). The differences between groups were analyzed by one-way analysis of variance (ANOVA), followed by Duncan's multiple range tests. The level of statistical significance was set at $P<0.05$. The statistical software package SPSS 15.0 (SPSS, Inc., Chicago, IL, USA) was used for all data analyses.

\section{RESULTS}

Egg production and live body weight gain of laying hens were influenced by supplementation with PAA (Table 3). Laying hens in both T2 and T3 had significantly higher HDEP, HHEP, and live body weight gain than laying hens in the control group $(\mathrm{P}<0.05)$. The egg weight in treatment groups T1 and T2 were not significantly different from egg weights in the control group. Physical appearance of the laying birds in treatment groups was better than that of laying hens in the control group, as they were heavier and densely covered with feathers. The results suggest that supplementing commercial corn soybean based diet $(17 \% \mathrm{CP})$ with PAA improves the egg production and live body weight gain of laying hens. The laying hens in the control group and all the treatment groups consumed all the feed provided at the rate of $110 \mathrm{~g}$ per hen per day. On the basis of this finding, it can be concluded that dietary supplementation of PAA upto $0.5 \%$ did not have adverse effects on daily feed intake.

Dietary supplementation with PAA had positive effects on the egg quality of eggs produced by the laying hens (Table 4). The external parameters including shell strength and shell thickness improved in the treatment groups as compared to the control group. The laying hens fed a basal diet with $0.05 \%$ PAA (T1) produced eggs with the highest shell strength and shell thickness. Eggs produced by laying hens in the $\mathrm{T} 3$ treatment had the highest $(\mathrm{P}<0.05)$ albumen ratio, whereas eggs 
produced by laying hens in the $\mathrm{T} 1$ treatment had the highest Haugh unit. However, increasing the PAA level above $0.05 \%$ did not improve the Haugh unit which indicated that PAA supplementation at $0.05 \%$ was adequate to improve egg quality.

Blood samples were collected at the end of the experiment. The concentrations of the all inflammatory marker were significantly lower in laying hens in PAA treatment groups than in laying hens in the control group, or there were no significant differences (Table 5), which indicated that PAA was not source of infectious agents. However, extensive studies are needed to clarify the specific effects of purified amino acid supplementation on intestine morphology and microflora of laying hens.

To evaluate the overall health condition of laying hens, plasma biochemical analyses were conducted.
Plasma glucose, total cholesterol and total bilirubin concentrations of laying hens differed significantly between laying hens in the PAA treatments and laying hens in the control treatments. The laying hens in control treatment had highest blood glucose level whereas laying hens in T2 treatment had highest total cholesterol and total bilirubin levels. As shown in Table 6, all parameters were within the normal ranges, indicating that purified amino acid supplementation had no negative effect on the health of laying hens.

\section{DISCUSSION}

Blood, an unavoidable by product of slaughter houses is a good source of protein (Bah et al., 2013). The use of blood derived proteins as feed ingredients has significant economic and environmental benefits. Tons

Table 3. Production performance of laying hen fed diets supplemented with different percentages of purified amino acid (PAA)

\begin{tabular}{|c|c|c|c|c|}
\hline \multirow{2}{*}{ Variables } & \multirow{2}{*}{$\begin{array}{c}\text { Control } \\
(0.00 \% \text { PAA })\end{array}$} & \multicolumn{3}{|c|}{ Treatments } \\
\hline & & T1 (0.05\% PAA) & T2 (0.1\% PAA) & T3 (0.5\% PAA) \\
\hline Average daily egg production & $15.91 \pm 3.6^{\mathrm{a}}$ & $16.02 \pm 3.4^{\mathrm{a}}$ & $17.66 \pm 2.7^{\mathrm{b}}$ & $17.71 \pm 3.1^{\mathrm{b}}$ \\
\hline $\begin{array}{l}\text { Total egg production during the } 60 \text {-days } \\
\text { experimental period }\end{array}$ & $891.00 \pm 3.6^{a}$ & $897.00 \pm 3.4^{\mathrm{a}}$ & $989.00 \pm 2.7^{b}$ & $992.00 \pm 3.1^{b}$ \\
\hline Hen day egg production (HDEP), \% & $48.69 \pm 8.4^{\mathrm{a}}$ & $49.80 \pm 8.7^{a}$ & $53.63 \pm 6.9^{b}$ & $54.86 \pm 8.5^{b}$ \\
\hline Hen house egg production (HHEP), \% & $45.46 \pm 8.4^{\mathrm{a}}$ & $47.49 \pm 9.8^{\mathrm{a}}$ & $51.56 \pm 6.3^{b}$ & $53.14 \pm 7.7^{b}$ \\
\hline Egg weight, g/hen/day & $63.48 \pm 1.7^{a}$ & $63.49 \pm 1.2^{\mathrm{a}}$ & $63.63 \pm 1.6^{\mathrm{a}}$ & $64.03 \pm 1.0^{\mathrm{b}}$ \\
\hline Live body weight gain $(\mathrm{kg})$ & $0.02 \pm 0.01^{\mathrm{a}}$ & $0.04 \pm 0.01^{\mathrm{a}}$ & $0.06 \pm 0.03^{\mathrm{b}}$ & $0.08 \pm 0.02^{\mathrm{b}}$ \\
\hline
\end{tabular}

Note: All data are presented as means \pm SD $(n=34)$. Means in the same row with different superscripts differ significantly $(P<0.05)$.

Table 4. Internal and external egg characteristics of egg produced by laying hen fed diets supplemented with different percentages of purified amino acids (PAA)

\begin{tabular}{lcccc}
\hline \multirow{2}{*}{ Variables } & Control & \multicolumn{3}{c}{ Treatments } \\
\cline { 3 - 5 } & $(0.00 \%$ PAA $)$ & T1 $(0.05 \%$ PAA $)$ & T2 $(0.1 \%$ PAA $)$ & T3 $\left(0.5^{\circ}\right.$ PAA $)$ \\
\hline Shell strength, kgf & $3.36 \pm 0.3^{\mathrm{a}}$ & $3.62 \pm 0.2^{\mathrm{b}}$ & $3.65 \pm 0.3^{\mathrm{b}}$ & $3.60 \pm 0.3^{\mathrm{b}}$ \\
Shell thickness, mm & $0.66 \pm 0.02^{\mathrm{a}}$ & $0.71 \pm 0.04^{\mathrm{b}}$ & $0.70 \pm 0.04^{\mathrm{ab}}$ & $0.69 \pm 0.01^{\mathrm{ab}}$ \\
Shell color & $9.84 \pm 0.6^{\mathrm{a}}$ & $9.84 \pm 0.5^{\mathrm{a}}$ & $10.71 \pm 0.5^{\mathrm{b}}$ & $9.59 \pm 0.5^{\mathrm{a}}$ \\
Yolk ratio, \% & $44.00 \pm 0.02$ & $43.00 \pm 0.02$ & $45.00 \pm 0.03$ & $44.00 \pm 0.03$ \\
Albumen height, mm & $6.17 \pm 0.5$ & $6.50 \pm 0.9$ & $5.99 \pm 1.1$ & $5.84 \pm 1.0$ \\
Albumen width, mm & $65.86 \pm 2.6^{\mathrm{a}}$ & $67.12 \pm 4.1^{\mathrm{b}}$ & $66.41 \pm 3.8^{\mathrm{ab}}$ & $66.89 \pm 3.6^{\mathrm{ab}}$ \\
Albumen ratio, \% & $53.00 \pm 0.64^{\mathrm{a}}$ & $56.00 \pm 0.07^{\mathrm{ab}}$ & $55.00 \pm 0.07^{\mathrm{a}}$ & $59.00 \pm 0.05^{\mathrm{b}}$ \\
Yolk albumen ratio, \% & $82.00 \pm 0.1^{\mathrm{b}}$ & $78.00 \pm 0.2^{\mathrm{ab}}$ & $85.00 \pm 0.2^{\mathrm{b}}$ & $74.00 \pm 0.1^{\mathrm{a}}$ \\
Haugh unit & $72.53 \pm 2.8^{\mathrm{a}}$ & $81.28 \pm 4.6^{\mathrm{b}}$ & $77.17 \pm 6.1^{\mathrm{ab}}$ & $72.56 \pm 5.6^{\mathrm{ab}}$ \\
\hline
\end{tabular}

Note: All data are presented as means \pm SD $(n=12)$. Means in the same row with different superscripts differ significantly $(P<0.05)$.

Table 5. Plasma concentrations variables associated with the immune response of laying hens fed diets supplemented with different percentages of purified amino acid (PAA)

\begin{tabular}{|c|c|c|c|c|}
\hline \multirow{2}{*}{ Variables } & \multirow{2}{*}{$\begin{array}{c}\text { Control } \\
(0.00 \% \text { PAA })\end{array}$} & \multicolumn{3}{|c|}{ Treatments } \\
\hline & & T1 (0.05\% PAA) & T2 (0.1\% PAA) & T3 (0.5\% PAA) \\
\hline $\mathrm{IgA}, \mathrm{ng} / \mathrm{mL}$ & $0.10 \pm 0.0$ & $0.10 \pm 0.0$ & $0.13 \pm 0.0$ & $0.10 \pm 0.0$ \\
\hline $\mathrm{IgG}, \mu \mathrm{g} / \mathrm{mL}$ & $0.81 \pm 0.0$ & $0.81 \pm 0.0$ & $0.80 \pm 0.0$ & $0.81 \pm 0.0$ \\
\hline $\mathrm{IL}-1, \mathrm{pg} / \mathrm{mL}$ & $0.18 \pm 0.0$ & $0.18 \pm 0.0$ & $0.18 \pm 0.0$ & $0.18 \pm 0.0$ \\
\hline $\mathrm{IL}-2, \mathrm{pg} / \mathrm{mL}$ & $0.08 \pm 0.0$ & $0.08 \pm 0.0$ & $0.08 \pm 0.0$ & $0.08 \pm 0.0$ \\
\hline $\mathrm{IFN} \gamma, \mathrm{pg} / \mathrm{mL}$ & $0.42 \pm 0.1^{\mathrm{b}}$ & $0.44 \pm 0.02^{\mathrm{b}}$ & $0.59 \pm 0.2^{c}$ & $0.30 \pm 0.99^{a}$ \\
\hline $\mathrm{TNF} \alpha, \mathrm{pg} / \mathrm{mL}$ & $0.74 \pm 0.4^{\mathrm{d}}$ & $0.44 \pm 0.2^{\mathrm{b}}$ & $0.28 \pm 0.3^{a}$ & $0.66 \pm 0.2^{c}$ \\
\hline
\end{tabular}

Note: All data are presented as means \pm SD $(n=10)$. Means in the same row with different superscripts differ significantly $(\mathrm{P}<0.05)$. 
Table 6. Results of plasma biochemical analyses of laying hens fed diets supplemented with different percentages of purified amino acid (PAA)

\begin{tabular}{lcccc}
\hline \multirow{2}{*}{ Variables } & Control & \multicolumn{3}{c}{ Treatments } \\
\cline { 3 - 5 } & $(0.00 \%$ PAA $)$ & T1 $(0.05 \%$ PAA $)$ & T2 $(0.1 \%$ PAA $)$ & T3 $(0.5 \%$ PAA $)$ \\
\hline Glucose, $\mathrm{mg} / \mathrm{dl}$ & $200.00 \pm 21.40^{\mathrm{c}}$ & $177.40 \pm 19.00^{\mathrm{a}}$ & $181.60 \pm 36.80^{\mathrm{b}}$ & $178.70 \pm 20.60^{\mathrm{a}}$ \\
Total cholesterol , $\mathrm{mg} / \mathrm{dl}$ & $140.60 \pm 21.50^{\mathrm{a}}$ & $157.40 \pm 22.00^{\mathrm{a}}$ & $187.20 \pm 33.90^{\mathrm{c}}$ & $175.90 \pm 36.50^{\mathrm{b}}$ \\
Blood urea nitrogen, $\mathrm{mg} / \mathrm{dl}$ & $5.00 \pm 0.00$ & $5.00 \pm 0.00$ & $5.00 \pm 0.00$ & $5.00 \pm 0.00$ \\
Total bilirubin, $\mathrm{mg} / \mathrm{dl}$ & $0.17 \pm 0.10^{\mathrm{a}}$ & $0.38 \pm 0.20^{\mathrm{b}}$ & $0.86 \pm 0.60^{\mathrm{c}}$ & $0.34 \pm 0.20^{\mathrm{b}}$ \\
GOT, IU/L & $169.30 \pm 39.00$ & $187.80 \pm 6.70$ & $177.70 \pm 37.20$ & $201.90 \pm 29.90$ \\
\hline
\end{tabular}

Note: Normal range for plasma biochemical parameters is referenced from The Merck Veterinary Manual, 10 ${ }^{\text {th }}$ edition, 2010; Glucose: 180-400mg/dl;

Total cholesterol: 129-297 mg/dl; Total bilirubin: 0.01mg/dl; GOT: 10-400 IU/L.

All data are presented as means \pm SD $(n=10)$. Means in the same row with different superscripts differ significantly $(P<0.05)$.

of blood are generated in abattoirs each year which can be used in animal feed to boost its protein or amino acid content (Adhikari, 2018). The purified amino acids (PAA) used in the present study were prepared from the blood generated in a slaughterhouse. Blood collected from the slaughterhouses was processed to isolate the protein from other constituents. The processing of the blood increased the crude protein concentration to 93.37\%. According to Li et al. (2011), glutamine and leucine are the most abundant amino acids in blood meal. The glutamine $(8.87 \%)$ and leucine $(11.64 \%)$ contents were relatively higher in PAA. Utilization of blood and blood proteins in the feed chain not only improves feed quality but also largely solves environmental problems related to blood waste from slaughterhouses (Jayathilakan et al., 2012; Ofori \& Hsieh, 2014). Supplementing laying hens with different concentrations of PAA increased their egg productions and live body weight gains. This result agrees with the findings of Bunchasak et al. (2005) who found that higher dietary protein contents improved egg production of laying hens. According to Alagawany et al. (2016), the live body weight of laying hens improved in the hens supplemented with high levels (18\% and $20 \% \mathrm{CP}$ ) as to low protein diets $(12 \%, 14 \%$, and $16 \%)$. Similarly, Adeyemo et al. (2012) reported that higher levels of dietary protein lead to increases in egg production and egg weight, which resulted significant improvement in the feed to egg mass ratio. However, the result is contrary to the findings of Kingori et al. (2010) who reported the body weight of laying hens was not affected by dietary protein level.

In addition to overall protein availability, egg production is also affected by the availability of specific essential amino acids (Houston et al., 1995). The qualitative composition of the protein source is of immense importance as the quality of protein depends not only on its nitrogen content, but also on its composition and bioavailability of specific amino acids (Ravindran \& Bryden, 1999). Moreover, there should be perfect balance between the amino acids, as high intake of one amino acid and deficiency of another might have detrimental effects (Novak et al., 2004).

According to Novak et al. (2004), supplementation laying hens with amino acids, particularly lysine, increases albumen content, which is the major cause for increased egg weight. Similarly, Shafer et al. (1996) reported that increasing dietary supplementation of methionine resulted in increased egg weight, yolk and albumen weight and total solids in albumen and yolk. There is a thin line between meeting the amino acid requirements of laying hens and providing excess of certain amino acids, such as isoleucine (Peganova \& Eder, 2002). Excess dietary isoleucine results in a marked reduction in feed consumption in laying hens (Peganova \& Eder, 2003). Similarly, high dietary L-cysteine content (7 folds higher than required) results in acute metabolic acidosis (Baker, 2009).

The external as well as internal characteristics of egg such as shell strength, shell colour, shell thickness etc. are crucial as they influence consumer's acceptability and price of the egg (Tabeekh, 2011).The egg shell strength is related to the amount and thickness of the egg shell (Roberts, 2004). The plasma mineral profiles of laying hens are considered as one of the contributing factors for the egg shell quality (Palvik et al., 2009). Egg shell strength and thickness is an economically important trait and has a marked effect on the marketability of eggs (Melesse et al., 2013). However, egg shell color was not affected by dietary PAA supplementation. The PAA contains a considerable amount of calcium and phosphorous which might be the underlying cause for increased calcium availability. Dietary supplementation of calcium can improve egg shell quality (Kebreab et al., 2009). With increase in demand for liquid egg, egg powder yolk oil, the importance for interior characteristics such as yolk Index and Haugh unit is gaining more importance (Hanusova et al., 2015). Albumen is an important determining factor for internal egg quality. A higher albumen height and Haugh unit indicates better egg quality (Şekeroğlu \& Altuntaş, 2009; Oke et al., 2014). The albumen height and Haugh unit determines the viscosity of the thick albumen (Hanusova et al., 2015). Dietary protein and amino acid content have a considerable effect on Haugh unit (Roberts, 2004). Inclusion of PAA above $0.05 \%$ seems to lower the albumen height and Haugh unit. Exposure to ammonia adversely affects albumen quality (Roberts, 2004). The addition of PAA above $0.05 \%$ might have elevated the nitrogen concentration in the feces, and this in turn might have increased the ammonia concentration of the litter.

As the PAA is manufactured from animal blood; there is a possibility that it contains harmful microor- 
ganisms, toxins, and toxic metabolites (Ofori \& Hsieh, 2014). Thus, it is essential to rule out any possible harm caused by PAA prior to its inclusion in animal feed. Immunoproteins, such as $\operatorname{IgM}, \operatorname{IgA}$, IgE, and $\operatorname{IgG}$ increase during antigenic stimulation, usually from infectious agents (Bunchasak et al., 2005). Pathogenic organisms activate the gastrointestinal immune system, which is characterized by elevation of serum concentrations of TNF $\alpha$, IL-1 $\beta$, and IL-6 (Liu, 2015) which diverts large amount of energy that could be used for productive traits (Deng et al., 2012; Torrallardona \& Polo, 2016). Supplementation of PAA didn't elevate the plasma cytokine level in the laying hens which indicates that PAA doesn't impose any adverse effect on the health of the laying hens.

\section{CONCLUSION}

The dietary inclusion of different levels of purified amino acid (PAA) has positive effects in layers as inclusion of $0.5 \%$ PAA resulted in increased the egg production and $0.05 \%$ PAA improved egg quality traits. Moreover, supplementing laying hens with $0.5 \%$ PAA didn't affect the average daily feed intake or the health of the laying hens. Thus, PAA can be considered as a valuable protein supplement for the laying hens. However, further study should be carried out to analyze if PAA can replace the conventional sources of protein for laying hens.

\section{CONFLICT OF INTEREST}

The authors declare that they have no conflict of interest.

\section{ACKNOWLEDGEMENT}

The authors would like to thank the Korea Institute of Science and Technology Evaluation and Planning (Project No. 116153-02) for their financial support and Nanum Co., Ltd., South Korea for providing the purified amino acid.

\section{REFERENCES}

Adeyemo, G.O., S.A. Abioye, \& F.A. Aderemi. 2012. The effect of varied dietary crude protein levels with balanced amino acids on performance and egg quality characteristics of layers at first laying phase. Food Nutr. Sci. 3: 526. https://doi.org/10.4236/fns.2012.34074

Adhikari, B. B., M. Chae, \& D.C. Bressler. 2018. Utilization of slaughterhouse waste in value-added applications: recent advances in the development of wood adhesives. Polymers. 10: 176. https://doi.org/10.3390/polym10020176

Alagawany, M., M.A. El-Hack, M.R. Farag, R. Tiwari, S. Sachan, K. Karthik, \& K. Dhama. 2016. Positive and negative impacts of dietary protein levels in laying hens. Asian J. Anim. Sci.10:165-174. https://doi.org/10.3923/ ajas.2016.165.174

Ambardekar, A. A., R. C. Reigh, \& M. B. Williams. 2009. Absorption of amino acids from intact dietary proteins and purified amino acid supplements follows different time-courses in channel catfish (Ictalurus punctatus). Aquaculture. 291:179-187. https://doi.org/10.1016/j. aquaculture.2009.02.044

Bah, C.S., A.E.D.A. Bekhit, A.Carne, \& M. A. McConnell. 2013. Slaughterhouse blood: an emerging source of bioactive compounds. Compr. Rev. Food Sci. Food Saf. 12: 314-331. https://doi.org/10.1111/1541-4337.12013

Baker, D.H. 2009. Advances in protein-amino acid nutrition of poultry. Amino Acids 37: 29-41. https://doi.org/10.1007/ s00726-008-0198-3

Bunchasak, C., K. Poosuwan, R. Nukraew, K. Markvichitr, \& A. Choothesa. 2005. Effect of dietary protein on egg production and immunity responses of laying hens during peak production period. Int. J. Poult. Sci. 15:701-708. https://doi.org/10.3923/ijps.2005.701.708

Deng, W., X. F. Dong, J. M. Tong, \& Q. Zhang. 2012. The probiotic Bacillus licheniformis ameliorates heat stress-induced impairment of egg production, gut morphology, and intestinal mucosal immunity in laying hens. Poult. Sci. 91: 575-582. https://doi.org/10.3382/ps.2010-01293

Fearon, J., S.B. Mensah, \& V. Boateng. 2014. Abattoir operations, waste generation and management in the Tamale metropolis: Case study of the Tamale slaughterhouse. J. Public Health Epidemiol. 6: 14-19. https://doi.org/10.5897/ JPHE2013.0574

Hanusova, E., C. Hrnčár, A. Hanus, \& M. Oravcova. 2015. Effect of breed on some parameters of egg quality in laying hens. Acta Fytotechn Zootechn. 18: 20-24. https://doi.org/10.15414/afz.2015.18.01.12-24

Harms, R.H. \& G.B. Russell. 1993. Optimizing egg mass with amino acid supplementation of a low-protein diet. Poult. Sci. 72:1892-1896. https://doi.org/10.3382/ps.0721892

Haugh, R.R. 1937. The Haugh unit for measuring egg quality. United States Egg and Poultry Magazine. 43: 522-555.

Hejnfelt, A. \& I. Angelidaki. 2009. Anaerobic digestion of slaughterhouse by-products. Biomass \& bioenergy. 33: 1046-1054. https://doi.org/10.1016/j.biombioe.2009.03.004

Houston, D. C., D. Donnan, \& P. J. Jones. 1995. The source of the nutrients required for egg production in zebra finches Poephila guttata. J. Zoology. 235:469-483. https://doi. org/10.1111/j.1469-7998.1995.tb01763.x

Jayathilakan, K., K. Sultana, K. Radhakrishna, \& A. S. Bawa. 2012. Utilization of byproducts and waste materials from meat, poultry and fish processing industries: a review. J Food Sci. Technol. 49: 278-293. https://doi.org/10.1007/ s13197-011-0290-7

Kebreab. E., J. France, R. P. Kwakkel, S. Leeson, H. D. Kuhi, \& J. Dijkstra. 2009. Development and evaluation of a dynamic model of calcium and phosphorus flows in layer. Poult. Sci. 88: 680-689. https://doi.org/10.3382/ps.2008-00157

Keshavarz, K. \& R. E. Austic. 2004. The use of low-protein, lowphosphorus, amino acid-and phytase-supplemented diets on laying hen performance and nitrogen and phosphorus excretion. Poult. Sci. 83:75-83. https://doi.org/10.1093/ ps/83.1.75

Kingori, A.M., J.K. Tuitoek, H. K. Muiruri, \& A. M. Wachira. 2010. Effect of dietary crude protein levels on egg production, hatchability and post-hatch offspring performance of indigenous chickens. Int. J. Poult. Sci. 9: 324-329. https:// doi.org/10.3923/ijps.2010.324.329

Li, X., R. Rezaei, P. Li, \& G. Wu. 2011. Composition of amino acids in feed ingredients for animal diets. Amino Acids. 40: 1159-1168. https://doi.org/10.1007/s00726-010-0740-y

Liu, Y. 2015. Fatty acids, inflammation and intestinal health in pigs. J. Anim. Sci. Biotech. 6: 41. https://doi.org/10.1186/ s40104-015-0040-1

Melesse, A., W. Tiruneh, \& T. Negesse. 2011. Effects of feeding Moringa stenopetala leaf meal on nutrient intake and growth performance of Rhode Island Red chicks under tropical climate. Trop. Subtrop. Agroecosyst.14: 485-492.

Melesse, A., Z. Worku, \& Y. Teklegiorgis. 2013. Assessment of 
the prevailing handling and quality of eggs from scavenging indigenous chickens reared in different agro-ecological zones of Ethiopia. J. Environt. Occup. Sci. 2: 1-8. https:// doi.org/ 10.5455/jeos.20130104091334.

Mohammed, K.A.E.F., L. Sarmiento-Franco, R. SantosRicalde, \& J. F. Solorio-Sanchez. 2012. The nutritional effect of Moringa oleifera fresh leaves as feed supplement on Rhode Island Red hen egg production and quality. Trop. Anim. Health Prod. 44: 1035-1040. https://doi.org/10.1007/ s11250-011-0037-5

Moreki, J.C. \& B. Tiroesele. 2012. Termites and earthworms as potential alternative sources of protein for poultry. Intern. J. Agro. Veter. Med. Sci. 6: 368-376. https://doi.org/10.5455/ ijavms.174

Novak, C., H. Yakout, \& S. Scheideler. 2004. The combined effects of dietary lysine and total sulfur amino acid level on egg production parameters and egg components in Dekalb Delta laying hens. Poult. Sci. 83: 977-984. https:// doi.org/10.1093/ps/83.6.977

Ofori, J.A. \& Y. H. P. Hsieh. 2014. Issues related to the use of blood in food and animal feed. Critical Reviews Food Sci. Nutr. 54: 687-697. https://doi.org/10.1080/10408398.2011.60 5229

Oke, O.E., A.O. Ladokun, \& O. M. Onagbesan. 2014. Quality parameters of eggs from chickens reared in deep litter system with or without access to grass or legume pasture. Magnesium (mg/g). 1: 2-12.

Osada, T., R. Takada, \& I. Shinzato. 2011. Potential reduction of greenhouse gas emission from swine manure by using a low-protein diet supplemented with synthetic amino acids. Anim. Feed Sci. Technol. 166: 562-574. https://doi. org/10.1016/j.anifeedsci.2011.04.079

Pavlík, A., M. Lichovníková, \& P. Jelínek. 2009. Blood plasma mineral profile and qualitative indicators of the eggshell in laying hens in different housing systems. Acta Veterinaria Brno. 78: 419-429. https://doi.org/10.2754/avb200978030419

Peganova, S. \& K. Eder. 2002. Studies on requirement and excess of isoleucine in laying hens. Poult. Sci. 81: 1714-1721. https://doi.org/10.1093/ps/81.11.1714
Peganova, S. \& K. Eder. 2003. Interactions of various supplies of isoleucine, valine, leucine and tryptophan on the performance of laying hens. Poult. Sci. 82: 100-105. https://doi. org/10.1093/ps/82.1.100

Ramsay, S. L. \& D. C. Houston. 1998. The effect of dietary amino acid composition on egg production in blue tits. Proc. Biol. Sci. 265: 1401-1405. https://doi.org/10.1098/rspb.1998.0448

Ravindran, V. \& W. L. Bryden. 1999. Amino acid availability in poultry - In vitro and in vivo measurements. Aust. J. Agric. Res. 50: 889-908. https://doi.org/10.1071/AR98174

Roberts, J.R. 2004. Factors affecting egg internal quality and egg shell quality in laying hens. J. Poult. Sc. 41:161-177. https:// doi.org/10.2141/jpsa.41.161

Şekeroğlu, A. \& E. Altuntaş. 2009. Effects of egg weight on egg quality characteristics. J. Sci. Food Agric. 89: 379-383. https://doi.org/10.1002/jsfa.3454

Shafer, D. J., J. B. Carey, \& J. F. Prochaska. 1996. Effect of dietary methionine intake on egg component yield and composition. Poult. Sci. 75: 1080-1085. https://doi.org/10.3382/ ps.0751080

Sklan, D. \& Y. Noy. 2004. Catabolism and deposition of amino acids in growing chicks: effect of dietary supply. Poult Sci. J. 83: 952-961. https://doi.org/10.1093/ps/83.6.952

Tabeekh, M. A. S. A. 2011. Evaluation of some external and internal egg quality traits of quails reared in Basrah City. Basra J. Vet. Res. 10: 78-84.

Tenesa, M., T. C. Loh, H. L. Foo, A. A. Samsudin, R. Mohamad, \& A. R. Raha. 2016. Effects of feeding different levels of low crude protein diets with different Levels of amino acids supplementation on layer hen performance. Pertanika J. Trop. Agric. Sc. 39:543-555.

Torrallardona, D. \& J. Polo. 2016. Effect of spray-dried porcine plasma protein and egg antibodies in diets for weaned pigs under environmental challenge conditions. J. Swine Health Prod. 24: 21-28.

Wandita, T.G., N. Joshi, I.S. Nam, S. H.Yang, S. H. Park, \& S. G. Hwang. 2018. Dietary supplementation of purified amino acid derived from animal blood on immune response and growth performance of broiler chicken. Trop. Anim. Sci. J. 41:108-113. https://doi.org/10.5398/tasj.2018.41.2.108 